\title{
FOREWORD: INTERNATIONAL DISPUTE RESOLUTION IN NEW ZEALAND
}

As a trading nation and one that has always looked to the wider world, New Zealand's engagement internationally is key to the country's well-being and prosperity. As New Zealand's engagement grows in an increasingly complex and global world, so does the potential for disputes and the need to resolve them fairly and efficiently. International dispute resolution is thus central to New Zealand's future. However, five years ago it seemed that there was a lack of awareness, and that understanding of issues in regard to international dispute resolution was not high within New Zealand's legal community. The reasons for this phenomenon are still not clear. It seems to be partly due to a lack of clients who engage in international transactions of a magnitude where dispute resolution becomes a major concern, but also due to the fact that the New Zealand court system is still relatively efficient, predictable and cheap. Or it might have been, as one practitioner has mentioned, that New Zealand lags slightly behind the international development.

Since 2012 the New Zealand Law Foundation has funded what has become the New Zealand Law Foundation International Dispute Resolution Fellowship. The fellowship, which is administered jointly by the Auckland University Law School and Victoria University's Law Faculty, is awarded each year to a renowned expert in the area of international commercial dispute resolution. ${ }^{1}$ During her or his time in New Zealand, the fellow is tasked to give the New Zealand Law Foundation Dispute Resolution annual lecture, alternating between Wellington and Auckland. In addition, the fellow will give a seminar in the other centre and will traditionally take part in at least one breakfast meeting of the Arbitrators' and Mediators' Institute of New Zealand (AMINZ). Depending on the interest and research area of the fellow, he or she might give additional seminars, workshops or talks. A very important fixture is also the Bankside Chamber lunch, which allows members of New Zealand's international arbitration community to engage with the fellow in a more informal setting. The importance of the fellowship, and the accompanying annual lecture and the additional seminars and workshops, has lied in making New Zealand's legal community aware of issues which are at the forefront of debate internationally, thereby keeping the legal community

1 The international dispute resolution fellows were: 2012 - Lucy Reed: co-head, global arbitration group, Freshfields Bruckhaus Deiringer; 2013 - Professor Catherine Rogers: Professor of Law and Price Faculty Scholar at Penn State Law, and Professor of Ethics, Regulation and the Rule of Law, Queen Mary, University of London; 2014 - Professor Thomas Stipanowich: William H Webster Chair in Dispute Resolution and Professor of Law at Pepperdine University, as well as Academic Director of the Straus Institute for Dispute Resolution; and 2015 - Adriana Braghetta, Professor and Coordinator of the Arbitration Course at IICS-CEU São Paulo, and co-head, arbitration group, LO Baptista-SVMFA (Brazil). 
abreast of international developments, and providing an opportunity for New Zealand to discuss the issues with world leading experts in their field. The yearly international dispute resolution week is now an established part of the yearly legal calendar. And it seems that the international dispute resolution fellowship has created a buzz. Since the inauguration of the fellowship, a greater engagement with issues of international dispute resolution has developed. 2015 alone saw the visit of John Beechy, President of the International Chamber of Commerce (ICC) Court of Arbitration and Gary Born, one of the world's leading international arbitration experts, sparking a discourse on international arbitration issues, including the value of investor-state arbitration and changes to the domestic arbitration framework. The discourse on Born's proposed Bilateral or Multilateral Arbitration Treaty regime ${ }^{2}$ in New Zealand to date is an indication that international arbitration issues are much less an exotic topic in 2015 than even five years ago. In addition, the discussion in regard to the Trans Pacific Partnership Agreement ${ }^{3}$ has brought international arbitration issues to the forefront. Lucy Reed's international dispute resolution lecture in 2012 addressed many of the issues being discussed in New Zealand in 2015, illustrating the significance of the New Zealand International Dispute Resolution Fellowship. ${ }^{4}$ As Catherine Rogers pointed out in her lecture: ${ }^{5}$

\footnotetext{
... the Law Foundation, you bring an international arbitration person here to share ideas and exchange ideas, as I have been in various different groups and will continue to be doing throughout the week. But even beyond these local exchanges, I will take back with me wherever I go these very firm thoughts about New Zealand and its place in the world and the world of international arbitration, as I am sure Lucy did and as how others who follow surely will.
}

In this issue of the Victoria University of Wellington Law Review (VUWLR), the reader is treated to some innovative and insightful discussions into the world of international arbitration. Catherine Rogers explores arbitrator selection in international arbitration and discusses the Arbitration Intelligence project. The Arbitration Intelligence project is the most innovative idea to promote fairness and transparency in international arbitration. ${ }^{6}$ Thomas Stipanowich's article

2 See Petra Butler and Campbell Herbert "Access to Justice vs Access to Justice for Small and Medium-Sized Enterprises: The Case for a Bilateral Arbitration Treaty" (2014) 26 NZULR 186. The draft treaty and commentary can be found at: "Model Bilateral Arbitration Treaty Released For Public Comment" (13 March 2015) WilmerHale <www.wilmerhale.com>.

3 See "Trans-Pacific Partnership" Ministry of Foreign Affairs and Trade <www.tpp.mfat.govt.nz>.

4 Lucy Reed and Robert Kirkness "Old Seeland, New Netherland and New Zealand: Some Thoughts on the Possible 'Discovery' of Investment Treaty Arbitration in New Zealand" (2012) 43 VUWLR 687. This article is based on the inaugural New Zealand Law Foundation International Dispute Resolution Lecture, entitled "Zealand Old and New: International Arbitration and Trade", delivered by Lucy Reed at Victoria University of Wellington on 7 November 2012.

5 Catherine Rogers "A Window into the Soul of International Arbitration: Arbitrator Selection, Transparency and Stakeholder Interests" (2015) 46 VUWLR 1179.

6 Arbitrator Intelligence <www.arbitratorintelligence.org>. 
privileges VUWLR to publish for the first time some insightful data from a survey among mediators. In light of the significant developments in international mediation in the past few decades, the article reflects upon and discusses current trends and tendencies. Lastly, Adriana Braghetta brings her experience as an arbitrator in Latin America to New Zealand and allows the reader a unique perspective on some of the most pressing issues in international arbitration, particularly in relation diversity amongst arbitrators.

Petra Butler

December 2015 
